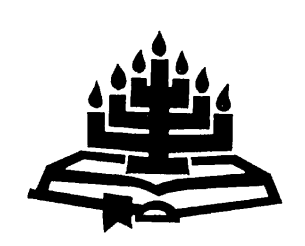

\title{
Paul and love patriarchalism: Problems and prospects
}

\author{
K. Syreeni \\ Department of New Testament \\ University of Uppsala \\ UPPSALA \\ Sweden \\ E-mail: Kari.Syreeni@teol.uu.se
}

\begin{abstract}
Paul and love patriarchalism: Problems and prospects

The term "love patriarchalism" (Liebespatriarchalismus) was coined in the 1970s by Gerd Theissen in his seminal sociological studies on Paul and the Corinthian community. The idea of "love patriarchalism" itself goes back to Ernst Troeltsch, who in his publication, Die Soziallehren der christlichen Kirchen und Gruppen (1912), described the social relations of early Christian, in particular in Pauline communities, as representing a "Typus des christlichen Patriarchalismus". Troeltsch stressed the conservative basic outlook of this strand of Christianity, and noted that this "religiöse Patriarchalismus" was marked by the ideal of love, a hierarchic church structure, and a certain view of family relations.
\end{abstract}

The Troeltsch-Theissen concept has been criticised by feminist and liberation-theological scholars for its political conservatism. While this criticism is understandable, but in itself no less politically conditioned, the exegetical problems rather lie in the generalising nature of the concept. However, it depicts one extremely influential post-Pauline stream of tradition, and raises vital questions concerning Paul's contribution to this development.

\section{Opsomming}

Paulus en 'n partriargalisme van liefde: probleme en moontlikhede

Die term, "n patriargalisme van liefde" (Liebespatriarchalismus), is in die sewentigerjare gemunt deur Gerd Theissen in sy kernstudie oor Paulus en die sosiologiese aard van die Korintiese gemeenskap. Hierdie idee oor patriargalisme self, kan herlei word na Ernst Troeltsch wat in sy publikasie, Die Soziallehren der christliche Kirchen und Gruppen (1912), die sosiale verhoudings binne die 
vroeg-Christelike, en veral die Pauliniese gemeenskappe, beskryf het as 'n tipe Christelike patriargalisme. Troeltsch benadruk die basiese konserwatiewe siening van hierdie tipe Christendom, en merk op dat hierdie "religieuse patriargalisme" gekenmerk was deur die ideaal van liefde, 'n hiërargiese kerkstruktuur en 'n sekere perspektief op gesinsverhoudings.

Troeltsch en Theissen se konsep van 'n patriargalisme van liefde is deur feministiese and liberalistiese teologiese navorsers gekritiseer op grond van die politieke konserwatisme daarvan. Hierdie kritiek is myns insiens verstaanbaar, maar is nie minder polities bepaald as 'n konserwatiewe siening nie; die eksegetiese probleme met "n patriargalisme van liefde" lê eerder in die veralgemenende aard daarvan. Hierdie konsep beskryf egter 'n invloedryke post-Pauliniese uitvloeisel van tradisie en laat kardinale vrae oor Paulus se bydrae tot hierdie ontwikkeling na vore kom.

\section{Introduction: The Troeltsch-Theissen concept and its critics}

The term "love patriarchalism" (Liebespatriarchalismus) was coined in the 1970s by Gerd Theissen in his seminal sociological studies on Paul and the Corinthian community. According to Theissen (1982:107-108), this social and religious ethos in early Hellenistic Christian communities represents a "moderate conservatism" that "takes social differences for granted but ameliorates them through an obligation of respect and love, an obligation imposed upon those who are socially stronger". Within the New Testament, we encounter the ethos of love patriarchalism "particularly in the deutero-Pauline and Pastoral Letters, but it is already evident in Paul (in 1 Cor. 7:21ff; 11:3-16)". Its main function is "to integrate members of different strata", and this it did so effectively that it in fact produced the church's fundamental norms and fashioned lasting institutions. It solved problems of organisation and prepared Christianity to receive the great masses. It even became significant for society as a whole, providing "a realistic solution" to the problem of social integration.

The main perspective from which Theissen identified and described the phenomenon of love patriarchalism was thus its integrative social function. Being a historical "ideal type" (Idealtyp in a Weberian sense), the notion of love patriarchalism has a concrete point of departure, a typical articulation against which other similar phenomena are measured. This historical archetype was provided by the mainly Gentile Christian, post-Pauline group of communities in Asia Minor and Greece at the end of the first century. At the same time, however, Theissen postulates a large-scale socio-historical trajectory, extending from Paul to the Constantinian church. In some respects, though with less stress on the development of theological ideas, this aspect of love patriarchalism 
corresponds to the problematic notion of "early Catholicism". Both concepts image the early stage of the expanding and compromising "Great Church" that came to imprint the whole Western world over a thousand years.

The idea of love patriarchalism goes back to at least Ernst Troeltsch, who in his Die Soziallehren der christlichen Kirchen und Gruppen (Troeltsch, 1912) described the social relations of early Christian, particularly Pauline communities, as representing a "Typus des christlichen Patriarchalismus". Troeltsch stressed the conservative basic outlook of this form of Christianity, and noticed that this "religiöse Patriarchalismus" was marked by the ideal of love, a hierarchic church structure, and a certain view of family relations. Troeltsch depicted a line of development from the early church via Paul to "early Catholicism", tracing this "type of Christian Patriarchalism" rather unhesitatingly back to Paul, indeed asserting that social conservatism is the essence of Christianity at large: "Das Christentum wird immer instinktiv sich ablehnend verhalten gegen alle Gleichheitsideen trotz seiner nahen Verwandschaft mit ihnen" (Troeltsch, 1912:65). This statement was based on the notion that the dualistic belief in predestination marks off the Christian idea of equality from its secular counterparts.

Theissen's reconceptualization of love patriarchalism differs from Troeltsch's in being more nuanced and sociologically grounded. Theological ideas such as predestination have a very subordinate role in Theissen's interpretation. Obviously, too, Theissen would not subscribe to Troeltsch's speculative view of the conservative nature of Christian basic "instincts". Yet, in his overall understanding of the historical development and the social forms of Christianity, Theissen explicitly builds on Troeltsch's distinctions. Theissen distinguishes love patriarchalism as one of three social forms of Christian faith, that is

... itinerant radicalism, love patriarchalism, and gnostic radicalism. In them three types are seen whose development Troeltsch follows through the entire history of Christianity - sect, established church, and spiritualism. The ethos of itinerant radicalism repeatedly came to life in sect-type movements such as Montanism, Syrian itinerant asceticism, the mendicant monks of the Middle Ages and the left wing of the Reformation. Gnostic radicalism was expressed in recurring individualistic and mystic conventicles within and outside the church. But we have to thank Christian love patriarchalism for the lasting institution of the church. With success and wisdom it tempered early Christian radicalism sufficiently so that the Christian faith became a life-style that could be practised collectively (Theissen, 1976: 91). 
In this bird's-eye view, historical and sociological categories coincide in an impressive way. Yet apart from exegetical issues, the suspicion of a hidden political agenda is easily raised. That Theissen distances himself from love patriarchalism as a model for present-day church and society, shows considerable sympathy for it as a well-functioning historical system. It is then hardly surprising that the Troeltsch-Theissen notion of early Christian love patriarchalism has been criticised by some feminist and liberationist scholars. This historical construction seems to imply, as Elisabeth Schüssler Fiorenza (1983:82) remarks, that "the gradual patriarchalization of the early Christian movement was unavoidable". Moreover, to describe the compromise between radical early Christian ethos and the larger society's patriarchal value system as a sign of "success and wisdom" sounds provocative. Should we agree that moderate social conservatism was the only viable way for the church, or was it rather a sad sign of succumbing to "the wisdom of this age" (1 Cor. $2: 6)$ ? Along the radical political path, quite opposite wisdom has been found in Paul, for instance by Neil Elliott in his Liberating Paul (1994). Within a more traditional theological framework, Klaus Schäfer in his monograph, Gemeinde als Bruderschaft (1989), contrasts Paul's egalitarian idea of brotherhood ( $\phi(\lambda \alpha \delta \in \lambda \phi i \alpha)$ with the patriarchal model of household. From a social-historical and economical perspective, Theissen's assumption of the social stratification of Pauline communities has recently been challenged by Justin J. Meggitt. In his Paul, poverty and survival (1998), Meggitt issues a massive attack on Theissen's theory and offers "mutualism" as an alternative explanatory model. Though not overtly political, this model too may strike one not only as "perhaps anachronistic for describing a first-century practice" but even as an ideological programme, since Meggitt makes clear that his term is historically "indicative of wide-ranging political, economic and social aspirations" (Meggitt, 1998:157).

If the Troeltsch-Theissen concept of love patriarchalism is suspect on ideological grounds, it seems as if feminist and liberation-theological criticism, as well as the proposed theological (brotherhood) and socioeconomic (mutualism) models, are no less ideologically engaged. In this article, my focus is mainly exegetical, i.e., secondary hermeneutical, even though I try to elucidate some general hermeneutical issues behind the exegetical discussion. In particular, I address the problem of Paul's relation to love patriarchalism. Hereby I already assume that love patriarchalism is a useful theoretical construct and points to something that was a social reality for many early Christians. It is instructive that Schüssler Fiorenza herself, while criticising Theissen's interpretation for ideological biases, employs the very concept as she commends feminist sociological models for exploring "the a-familial character and the love 
patriarchalism of the early Christian movement" (Schüssler Fiorenza, 1983:91). Obviously, the term does describe a real phenomenon though it can be determined and evaluated differently according to one's ideological priorities.

\section{Defining love patriarchalism}

To avoid premature generalisations, it seems advisable to draw a sharper line than Theissen does between love patriarchalism as a social "ideal type" and as a historical phenomenon. A further distinction is to be made between a large-scale "trajectory" and a more punctual historical system. The problems inherent in the concept of "trajectory" have been discussed keenly since Robinson and Koester's Trajectories through early Christianity (1971). In addition to the deterministic bent, the risk I find especially impending in this case is that the trajectory conforms to a stereotyped plot which, depending on the interpreter, proceeds from paradise to fall or from youthful idealism to mature adulthood, with the end relating to the beginning either as a lump to the unholy leaven or as a great tree to a small seed. That makes a good story and an interesting scholarly case, but historical change is mostly a complex phenomenon, allowing many more stories.

Choosing the more punctual mode of description, which is methodologically safer and ideologically less engaging, we arrive at a narrow understanding of love patriarchalism as the religiously motivated patriarchal ethos expressed in Colossians, Ephesians and the Pastoral Letters. Still narrower, it is the ethos of the household codes as it appears in these letters (Col. 3:18-4:1; Eph. 5:22-6:9; 1 Tim. 2:8-15, Titus 2:1-10; cf. 1 Tim. 6:1-2; 1 Peter 2:18-3:7). This may well be too narrow a definition, but it is a relatively safe point of departure. It is not extremely narrow, since the household rules naturally have to be interpreted in their literary contexts as well as in their wider social and historical setting.

The immediate consequence of this relatively strict delimitation is that it describes previous developments in relation with this ideology, and in some cases as factors that have contributed to its formation, but not as parts of it (as with "trajectory"). The description regards contemporary phenomena, such as the Matthaean or Johannine communities, as distinct points of comparison, not as belonging to alternative major types of Christianity (as with "ideal types"). Later church history is not conceived as the natural result of this "winning concept" but as the sum of previous contributions, including the kind of love patriarchalism advanced in post-Pauline communities. The contributional approach I am suggest- 
ing by no means precludes, but only precedes the more synthetic (and dangerous) step of constructing historical routes or "trajectories".

This interpretative strategy may appear overcautious, at worst tendentious, as if the underlying idea were to separate Paul from later arbitrary developments. Such tendencies are not unusual. When, for instance, Richard A. Horsley (1998:158) is critical of Theissen's "projection of deutero-Pauline 'love patriarchalism' back onto Paul himself", the underlying conviction implies that Paul bespoke an counter-imperial, international society of people loyal to the enthroned Christ (Horsley, 1998a: 176), a programme rightly understood by those groups who gathered resources to free their members from slavery but were neglected by the communities of the deutero-Pauline letters who simply accepted the fundamental social form of the slave-holding patriarchal household (Horsley, 1998a:176196). In my opinion, what calls for caution is not the need to whitewash Paul, but the scholarly desire to avoid oversimplifications. Paul's contribution to the full-blown love patriarchalism of the Pastoral Letters is not so straightforward as is sometimes suggested; but neither was the ethos of the household codes a mere falling from the supposedly egalitarian Pauline gospel.

The word ethos in my definition deserves attention. One pitfall of interpretation is to compare patriarchalism and the Christian ideal of mutual love on a par, which inevitably leads to a distorted picture. An ideal is an abstract ideological entity unless it is embodied as ethos, which Leander E. Keck (1974:440) defines as the gathering up of "the practices and habits, assumptions, problems, values, and hopes of a community's lifestyle". Ethos includes abstract ideal elements - "values" and "hopes" - that motivate or at least legitimate the group's actual "practices and habits". The individual or the group may well perceive the actual "practices and habits" differently from how outsiders see them, indeed how these practices are in reality. Ethos implies therefore a more or less sympathetic inside (emic) mode of description, where the practitioners' own ideals and intentions are included. The function of a social system is still remoter from theological ideals as it includes unintentional, objective functions that members of the group are unaware of. (For Theissen's functionalism, see Schütz 1982:16-17.) To directly juxtapose Paul's religious ideal of love and the actual ethos (not to speak of the covert functions) of the patriarchal society would be as grave a methodological mistake as taking myth for concrete reality.

Moreover, the patriarchal ethos of the larger Jewish and Hellenistic society is, sociologically seen, more basic and embracing than the emerging Christian symbolic universe. Whatever happened to Paul at his conversion, or to early Christians at baptism and when entering the 
community life, the new religious ideology did not demolish at once all that they had learnt about societal values, practices and prejudices they had about purity and impurity, honour and shame, and so on. And even if much was changed and reinterpreted, we have to reckon with the impact of inherited social patterns on processes of metaphorization. By metaphorization, I do not only mean Paul's use of metaphors as an aesthetic, text-world device. This aspect of Paul's metaphorical language is conveniently presented in David J. Williams's book on Paul's metaphors (1999). But there is also the deeper symbolic level of metaphorical thinking and perception, where Paul's metaphors are not means of saying something (else) but the very thing he is saying. Besides linguistically identifiable metaphors, metaphorical thinking includes other culturally determined cognitive processes of comparison and modelling. When Paul spoke of sin as "slavery" and of becoming "slaves of God" (Rom. 6:22), these are more than linguistical metaphors, for obviously Paul's conception of slavery as a social phenomenon informed his religious understanding of what sin and obedience to God actually are. Similarly, in early communities and for Paul "family" was not only a social reality, it also provided a profound source for metaphorical thinking, which in turn affected the communities' social life. (See the articles in Moxnes, ed., 1997.)

\section{Problems concerning authenticity and sources}

The issues of authenticity and pseudepigraphy in the Pauline corpus, as well as the reliability of Acts in reconstructing Paul's person, mission and environment, are customarily recognised and discussed by scholars in this context. Yet in my opinion, these issues are still more crucial than is often recognised. Today there is a critical consensus on the authenticity of seven Pauline letters (1 Thess., Gal., 1-2 Cor., Rom., Phil., Phlm.). Colossians usually drawn relatively near Paul's time, Ephesians is dependent on Colossians and somewhat later, and the Pastoral Letters are indisputably later and pseudepigraphical. Since these five documents are constitutive to the concept of love patriarchalism, Elliott's plea for "facing the facts of pseudepigraphy" (Elliott, 1994:25) is urgent. He also points out that several scholars see interpolations in otherwise authentic letters (1 Thess. 2:14-16; 1 Cor. 14:34-35; Rom. 13:1-7 - and the list could be made longer). Despite his obvious tendency to expose "the canonical betrayal of the apostle", Elliott may be right in stressing that "the inauthentic letters have even contaminated the way we read Paul's genuine letters" (Elliott, 1994:25).

I wonder, however, if the critical consensus is really a safe foundation for further inquiry. It rather appears an easy compromise between extremes, and may conceal historical and literary development as much 
as it discloses it. On the one hand, there seems no great leap from the "genuine" letters to the Colossians letter, so the hesitation among many scholars concerning Colossians is quite understandable; and if Colossians is considered mainly authentic, then the next step to Ephesians seems not insurmountable. On the other hand, the literary integrity, indeed authenticity of the earlier prison letters might be questioned. Colossians 1:24 (the suffering Paul is in his flesh completing what is lacking in Christ's afflictions) and 2:1 (Paul's striving for "all who have not seen my face") seem to betray a later perspective, from which Paul is seen as a paradigmatic sufferer and prisoner who is metaphorically "alive" and still preaching the gospel, very much as in the concluding scene of Luke's Acts. But does not already the letter to the Philippians give a similar posture of Paul? Yet the authenticity of Philippians is practically no issue at all in recent scholarship, though its compositional integrity is frequently discussed and the mention of "bishops and deacons" in 1:1 is sometimes felt to be out of place.

Neither is there presently any disagreement on the authenticity of the short personal letter to Philemon. Peter O'Brien (1982:269) speaks for many in consigning the Tübingen school's stance to "the eccentricities of NT scholarship", stating that "(0)nly the most extreme negative critics have in the past disputed the Pauline authorship of the epistle". Still, some observations justify a measure of caution: the close relation of the letter with the disputed Colossians, the unclear situation presupposed in the letter, the description of Paul as $\pi \rho \in \sigma \beta u ́ \tau \eta \varsigma$ (v. 9), and the somewhat

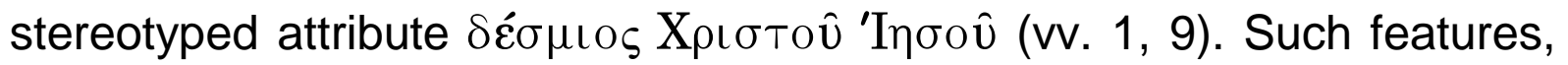
together with v. 22 (Paul's future plans), create a portrait of the apostle as an aged, paradigmatic prisoner for Christ's sake, yet alive and ready to come back any time if needs be. But of course, it is not impossible to imagine Paul deliberately painting such a self-portrait. (For a useful conventional survey of Paul's portrayal as a prisoner, see Wansink 1996.) The affectionate, witty rhetoric of the letter seems typically Pauline. The author of Colossians does not question the authenticity and authority of Philemon, as 2 Thessalonians seems to contest 1 Thessalonians. However, the sensitive slave issue that Philemon brought into focus may help explain the prominence of the exhortations to slaves (and masters) in Colossians 3:22-4:1.

Of the alleged interpolations, 1 Thessalonians $2: 13-16$ is not central to our theme but shows the problems one meets once suspicions about authenticity are raised. If Thessalonians is unpersonal and replete with phrases and themes from 1 Thessalonians, are not similar features found in parts of 1 Thessalonians? The situation usually assumed behind 1 Thessalonians is also problematic, as for instance Walter Schmithals 
has pointed out: during a few months' stay at Thessalonica, Paul has established a community with a functioning local leadership (5:12-13) and apparently with missionary workers spreading the gospel in Macedonia and Achaia (1:8), all that in the midst of poverty and persecutions from "the Jews". It is understandable that hypotheses have been put forward to find two letters by Paul, an earlier and a later one, in 1 Thessalonians. I think it is uncertain, however, if this manoeuvre is sufficient to defend the authenticity of all of Paul's Thessalonian letters, as Murphy-O'Connor (1997:102-129) has argued.

1 Corinthians 14:34-35 is deemed variously among critical scholars, and apparently on different ideological premises. Some ideological critical scholars willingly reject this unsuitable piece of male chauvinism as a forgery, while for others it is a warning example of the pervasiveness of patriarchal ideology even in Paul. Mainstream or conservative scholars may wish to dismiss the verses in order to maintain the image of Paul as a reasonably progressive theologian, but they may also feel obliged to accept its authenticity as an inconvenient fact that nevertheless can be "explained" as a time-bound influence from Paul's cultural environment, or as motivated by the special situation in Corinth and by Paul's concern for the good reputation of the community in the larger society. So the interpreter's ideological interests can cut both ways. Unfortunately, that does not make the exegetical solution any easier, because scholars also have quite diverging methodological preferences. Thus, e.g., the now popular rhetorical analysis tends to favour the unity of 1 Corinthians, while the various literary-critical hypotheses give a much more fragmentary picture of the compilation of Paul's Corinthian correspondence. Since I am personally inclined to take a literary- and redaction-critical view on Paul's letters, the interpolation hypothesis does not seem a priori implausible, all the more so since there is some disturbance in the manuscript tradition. There is tension between this statement and 1 Corinthians 11:5, where Paul seems to take for granted that women can pray and prophesy in the community's gatherings. Yet, the argument that Paul himself in principle could not possibly have slipped this "stubbornly patriarchal sliver" (Elliott, 1994:53), is to beg the question. Some exegetes hold, with reasonable though not compelling arguments, that 1 Corinthians 11:2-16 is also an interpolation (see, e.g., Horsley, 1998b:152-153). If so, the redaction history of 1 Corinthians is complex indeed.

This is not the place to argue for or against the authenticity of individual letters and sections in the Pauline corpus, or to hypothesise on the emergence of the redacted collection(s) of Paul's letters. My point is only that the scholarly consensus may need to be critically examined, also and especially when Paul's contribution to love patriarchalism is under 
discussion. If we are not ready to extend the notion of authenticity beyond the group of seven (which I deem problematic but not altogether implausible), and if we draw the full consequences of the complex Entstehungsgeschichte and compilation of at least 1-2 Corinthians, and probably of 1 Thessalonians, Philippians and Romans (12-16), we may have to reconsider the schematic division into seven wholly authentic and six pseudepigraphic letters. Such a re-evaluation might affect our image of the historical Paul. However, it is less certain that he will then appear decidedly more critical of the patriarchal society.

The use of the Acts of the Apostles as a source for reconstructing Paul's person, missionary practices and social setting is another much-debated issue. While scholars usually express caution, and unanimously remark that Paul's authentic letters are the primary source in these matters, I fear that the general attitude is still too credulous. Much lip service is still paid to this critical principle (rightly Murphy-O'Connor, 1997:vi). Apart from the all too neglected possibility, I would say probability, that Luke knew and used Paul's letters (notwithstanding the theological and chronological differences), there is the well-known Lukan tendency to idealise the early Christian communitites. This Tendenz is not unequivocal, because Luke may exaggerate the "communism" of the earliest Jerusalem community just as much as he overemphasises the wealth and social status of many Gentile members of the church. Anyhow, Meggitt's (1998:9) reserve is justified: Acts must be treated "with the degree of circumspection it deserves".

\section{Socio-economical issues: patronage vs. mutualism, household vs. "family"}

While problems concerning admissible literary sources are significant enough, it is the socio-economical issues that really lie at the heart of the exegetical disputes on Paul and love patriarchalism. Here, too, exegetical and ideological/theological concerns intermingle, not surprisingly, since the focal point concerns the distribution and execution of power, then (in Pauline and post-Pauline times) and now. In feminist and other ideological critical discourse, a distinction is often made between the (patriarchal, hierarchic, suppressive) "power over" and the (egalitarian, mutual, co-operative) "power with". In mainstream exegesis, these terms are easily dismissed as obscure or tendentious, but if it is agreed that they are abstract structural categories without value implications, then in fact these terms are quite convenient to describe what others would call (hardly more analytically) vertical and horizontal relations, or the like. Postmodern critics who conceptualise power otherwise, e.g., by applying Foucault's approach, are naturally right that the discourse or rhetoric of 
power is a much more intricate issue. Below, I introduce the terms "power from below" and "from within" to describe the more subtle processes of reversal and metaphorization in relation to the two axes of power.

Of the "power over" relations in Hellenistic societies of the early Christian era, especially two systems have attracted the exegetes' keen attention. Patronage, based on the vertical patron-client relation, is a prime example of the patriarchal system in a larger society (city). According to most scholars, references in the Pauline letters and in Luke's Acts to hospitality towards visiting missionaries and gathering a group of believers in one's house, show how the system of patronage with its respective benefices and obligations was part of life for early Christian groups (see Moxnes, 1995). On a smaller scale, household with its hierarchic structure from master (paterfamilias) to slave is the basic socio-economic unit and present in practically all social interchange. Both systems rely on the patriarchal ideal of a "father-owner" who takes care of those who are dependent on him. The same imagery was effective on the high political level, too, where the emperor was metaphorically the Father of the Fatherland. After the murder of Caesar, a marble column was put up in the Forum, with an inscription reading Parenti Patriae, and the Roman Senate named the day of the murder Parricidium. Augustus and most of his successors bore the title Pater Patriae (Lassen, 1997:110-114).

Thus there is no denying that patriarchal ideology penetrated the whole society, including the early Christian communities, and asserted itself in their social reality. It is equally clear, however, that many important social relations were based on mutual caring, such as friendship and intimate relations within the family, especially between mother and son, and increasingly also between husband and wife (Moxnes, 1997:31-35). To evaluate the relative importance of and the interconnections between these two axes of power is difficult, as is obvious already because of their conjunction on the level of a household/family: the subordination and mutual caring between man and wife, or father and son, and the still more intimate relations between mother and son and brothers and sisters. Seldom if ever is only one of the basic power structures at work; rather there is a network of hierarchic and non-hierarchic relations. Closest to mutuality is perhaps the relation between siblings, but even there the patriarchal order distinguishes the older brother from younger ones, and brothers from sisters.

The presence of patrons and clients in Pauline communities is a matter of some disagreement. Much of the evidence is found in the Corinthian letters and in Romans 16. Paul states in 1 Corinthians 1:26-29 that there 
are "not many" wise, powerful and of noble birth in the community. Theissen (1982:72) concluded that Paul's dictum implies that there were nevertheless some well-to-do and influential persons. The mention of some eminent individuals - such as Crispus (1 Cor. 1:14) who, according to Acts 18:8, was a synagogue ruler, Erastus "the city treasurer" (Rom. 16:23), and Aquila and Prisca who ran house churches (Rom. 16:3; 1 Cor. 16:19; cf. Acts 18:2, 18.26) - lends support to this conclusion, even though uncertainties concerning the date and value of these sources should be borne in mind. The problems Paul met in Corinth seem to add to the picture of a community with considerable social stratification. But there is disagreement whether this is really proof of a patronage system in the Pauline communities. Much depends on how the system of patronage is defined. The seven features described by John K. Chow (1992:30-33) are instructive but rather general: patronclient relation is an exchange relation, asymmetrical, usually informal and supra-legal, often binding, yet voluntary; and it is a vertical relation. A Christian householder who continually provided the facilities for community meetings and a room for visiting or resident missionaries meets the minimum requirements, especially if he or she was influential enough to provide some form of protection against outward pressure (from civil authorities, synagogue leaders, the mob). If only the $1 \%$ of the populace belonging to the real societal élite is by definition qualified as patrons, then of course it is disputable whether there were such in Paul's churches. The differences between individual communities must not be overlooked: what may be assumed for Corinth may not apply to Thessalonica. A further complication is that Christian patrons and benefactors may not always have been recognised as such. One might assume that an authoritative and self-conscious preacher like Paul could accept "hospitality" on a regular basis without admitting there being any clientship from his part. After all, that is what "brothers and sisters in Christ" are for, and in principle Paul thought he would have had the right to salary!

Since E.A. Judge's studies from 1960 on, a number of exegetes (for example L.W. Countryman, V.P. Furnish, C. Forbes, P. Marshall, J.A. Crafton, J.K. Chow [1992], J.S. Kloppenborg [1998], B.W. Winter [2001], and several others) have assumed the impact of the patronage system at least in the Corinthian setting, while some recent interpreters (besides Meggitt, see also Aejmelaeus, 2002:352-354) are unconvinced. Especially Meggitt's attempt to shatter this common opinion deserves discussion, because his critique directly challenges Troeltsch's and Theissen's concept of love patriarchalism and the "new consensus" that the Christian movement incorporated individuals from various strata of first-century society, including some from the higher strata. 
Meggitt is able to show that Theissen's criteria for assessing the wealth and social status of Paul's Corinthian friends - possession of offices, houses, offering of services and travel - are not waterproof, and that Theissen's application of the criteria is sometimes loose. His overall picture of the Pauline urban Christians as mainly poor people, helping one another as they could, may be closer to truth than, e.g., Bruce W. Winter's (2001:185) description of full-time paid Thessalonian retainers whose "hands had never known work" and who now should leave their patrons and become benefactors of the community. Yet Meggitt's effort to downplay the presence of patron-client and other vertical "power over" relations in the Pauline communities is not convincing. In his effort to diminish the impact of all other survival strategies besides mutualism, Meggitt dismisses insights that might lead to more balanced conclusions, especially concerning Paul's personal ethos. For instance, he concludes

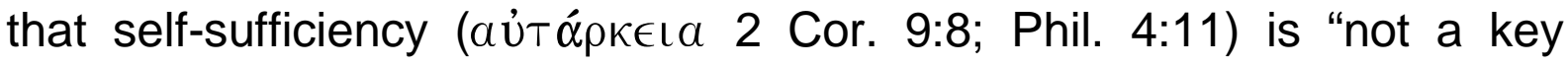
theme in Pauline Christian economic behaviour" (Meggitt, 1998:156), adding (in a footnote) a theological argument: for Paul, self-sufficiency is not accomplished through personal struggle but by the believer's relationship with Christ (Phil. 4:13). However, as Troels EngbergPedersen (2000:100-102) argues, precisely at this point Paul's participationist theology parallels the Stoic ideal of self-sufficiency. For Paul and the Stoics alike, real independence means belonging elsewhere, not in the material world but in the realm of logos (Stoics) or God/Christ and the Spirit (Paul). Paul has an unfailing "inner" strength (e.g., "power from within") through participation in Christ, which no earthly misfortune - nor wealth - can shatter. He was not really in need of the (belated) gift from the Philippians, though it was certainly nice of them to send it, and beneficial to themselves. Paul's (!) God will see to it (4:19). Here Paul tacitly reminds of the hierarchic relationship between him and the addressees.

In fact, the idea of a special (Christian, participationist) form of selfsufficiency surfaces also elsewhere in Pauline letters. In 1 Thessalonians 4:9-11, one of Meggitt's proof texts for mutualism, the teaching of $\phi \iota \lambda \alpha \delta \in \lambda \phi \dot{i} \alpha$ and $\tau o ̀ ~ \dot{\alpha} \gamma \alpha \pi \hat{\alpha} \nu \dot{\alpha} \lambda \lambda \hat{\eta} \lambda o v \varsigma$ is introduced unnecessarily, as it

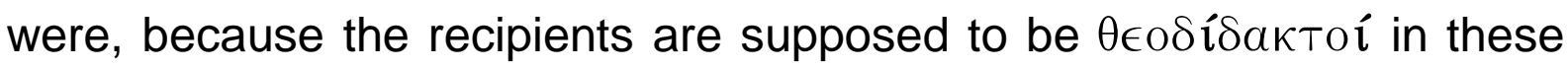
matters. The real point, towards which this paraenesis leads, is the exhortation that the addressees mind their own affairs in peace and quiet and work with their own hands, in order to command the respect of outsiders and "be dependent on nobody" ( $\mu \eta \delta \in \nu$ ò $\varsigma \chi \rho \in$ ía $\left.\tilde{\varepsilon}^{\prime} \chi \eta \tau \epsilon\right)$. The last remark, whether it is translated in this way (as in the RSV) or as "not needing anything", seems as remote from mutualism as it is from patronage. Self-sufficiency and mutual love need not be contrasted but 
are rather the two sides of a coin. Solidarity within the community means self-sufficiency in relation to the outside world.

A similar rationale seems to motivate Paul's second best advice in 1 Corinthians 6:1-6 that the Corinthian believers settle lawsuits among themselves, "the saints", instead of making it a public case before "the unrighteous". Paul's best piece of advice, given in the following verse (v. 7), is to have no lawsuits at all: "Why not rather suffer wrong?" This would imply that self-sufficiency be extended to the individual believer. Earthly wrongs and misfortunes can not really harm a person who is "in Christ" (cf. Rom. 8:35-39). The principle of self-sufficiency, coupled with the ideal of self-discipline, also motivates Paul's stance in marital issues. "To the unmarried and the widows I say that it is well for them to remain single as I do. But if they cannot exercise self-control, they should marry. For it is better to marry than to be aflame with passion" (1 Cor. 7:8-9). (For Paul's understanding of marriage as a means of avoiding sexual desire, see Martin, 1997.) Remaining single does not mean being alone, because the single one is "in" or "with" Christ. The Christian selfsufficiency is therefore not simply minding one's own business, but a way of devoting oneself to the Lord: "The unmarried man is anxious about the affairs of the Lord, how to please the Lord; but the married man is anxious about wordly affairs, how to please his wife" (1 Cor. 8:32-33). But Paul knew that not everybody had his specific gift of continence, and perhaps he thought it was better so. To impose celibacy on the whole church would have abolished the household structure, and with it, the "subtle chain of command by which his teachings were passed on to each local community through the authority of local householders" (Brown, 1988:54).

Meggitt's second witness is 2 Thessalonians 3:6-12, which he takes for authentic and providing "evidence that mutualism was a guiding assumption of economic relations, not only between but also within the communities" (Meggitt, 1998:162). This of course means reading the text between the lines, because the letter, like 1 Thessalonians, strongly discourages the addressees from being economically dependent. Instead they should imitate Paul: "We were not idle when we were with you, we did not eat anybody's bread without paying ..." In v. 10, the sound apostolic teaching is articulated harshly: "If any one will not work, let him not eat". But surely, if Theissen is justified to read 1 Corinthians $1: 26-29$ against the grain, then Meggitt is right to point out that the situation behind 1-2 Thessalonians differed from what the letter writers wanted it to be. It is conceivable that the problem tackled in 1 Thessalonians arose because of "a rather intense eschatological fervour" (Meggitt, 1998:162 n. 39). The interesting question is how typical such sentiments were in (post-)Pauline communities at large. 
Meggitt's most important piece of evidence is Paul's collection to the poor of Jerusalem. No doubt the collection was a matter of first priority for Paul, as the references to it in several letters indicate (Gal. 2:10; Rom. 15:25-32; 1 Cor. 16:1-4; 2 Cor. 8-9). But the stress laid on this particular collection is no proof that such campaigns were arranged between and within Paul's own communities. We never hear of similar organised collections, or of a permanent "community fund", we only learn that Paul occasionally received financial support from his churches (2 Cor. 11:9; Phil. 4:15-16) and from individual supporters (Rom. 16:1$2: 23)$. That Paul really should have thought of the Jerusalem collection in terms of economic reciprocation (Meggitt, 1998:160-161) is unlikely. For one thing, if the need was urgent and caused by a local food shortage, the time span indicated in 2 Corinthians 8:10 ("a year ago") is surprising; and if Acts is right in suggesting that the Jerusalem community rejected the gift, one wonders how badly it was needed. True, Paul's rhetoric in 2 Corinthians 8:14-15 does envisage something like economic mutualism, an idea that could even be developed into a social programme of

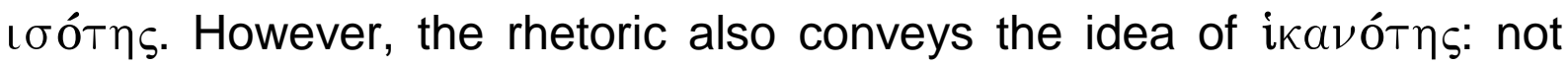
abundance, not lack of necessities of life, but enough for survival is best for the disciplined body. Besides, before introducing this practical paraenesis, Paul expressly gives a religious argument where vertical relations come to the fore: "For you know the grace of our Lord Jesus Christ, that though he was rich, yet for your sake he became poor, so that by his poverty you might become rich" (v. 9). Here, in what I suggest is the heart of Paul's religious stance in matters of power, we see the intrinsic dialectics of an unquestioned "power over" (Jesus as Master) and its seeming reversal "from below" (Jesus as Servant), joined together to motivate mutual care ("power with") and personal independence ("power from within").

\section{Metaphorizations and reversals: Paul, the parent's stigma and pride}

Even though we knew precisely what the historical Paul wrote, and knew the socio-economic situation in each community, still the subtleties of Paul's religious and social reasoning would make it difficult to assess to what extent he was promoting the ethos of love patriarchalism. Paul often used metaphorical language to revert hierarchic "power over" relations and combined these metaphorical "power from below" relations with non-hierarchic metaphors of family, brotherhood and body members. By so doing he blurred customary distinctions and left his interpreters, early as well as contemporary ones, in uncertainty about his real intent. 
When metaphorizing on the most notorious form of patriarchal subordination, slavery, his reversals are particularly ambiguous. Consider 1 Corinthians 7:22: "For he who was called in the Lord as a slave is a freedman of the Lord. Likewise he who was free when called is a slave of Christ." Is this liberation theology or extreme social conservatism, or neither? Paul's elliptic statement, $\mu \hat{\alpha} \lambda \lambda$ ov $\chi \rho \hat{\eta} \sigma \alpha$, in the preceding verse, causes an additional problem. Does he recommend manumission if the opportunity is given, or does he mean the slave should avail himself of his present position (as a slave)? But either way, the metaphorical reversals in themselves create a dilemma. Suppose Paul meant that the slave should avail himself of the offered manumission. The crux still remains that Paul seems to metaphorically equate slavery with freedom. If you are a slave, never mind - you are still free "in Christ", and your brother who is free is actually "a slave". This may be a profound theological truth, or just a cheap trick. It is such rhetoric that many contemporary interpreters of Paul find annoying. Metaphors are not innocent, nor do rhetorical reversals turn the real world upside down. But in part, the contemporary irritation is unfair. What more could we reasonably expect of Paul in his first-century context? "It is clearly preposterous", remarks the sociologist Orlando Patterson (1998:269), "to criticize Paul for not calling for the abolition of slavery, or for taking the Roman imperial slave system for granted". If we accept that Paul wrote the letter to Philemon, Patterson is right to conclude that "Paul was a humane, caring soul" and sympathetic to using all legal means for the manumission of (Christian) slaves. Patterson then adds that this was only wise of Paul, given the prominence of former slaves in his congregations. Of course, it was equally wise not to be too sympathetic to the freedom of the slaves. The few wealthier Christian householders, with their servants, were also very "useful" for Paul's purposes.

The slave imagery is typical of Paul. His customary self-designation "slave/servant of God/Christ" (Rom. 1:1; Gal. 1:1; Phil. 1:1) probably comes from Old Testament imagery. God is the supreme king, and being his servant is no lesser position than being a royal messenger, an apostle, as Richard A. Horsley (1998:168-169) points out. However, Horsley's attempts to do away with the darker sides of Paul's slave imagery are less compelling. The Old Testament image of God's royal rule is in itself highly patriarchal, and Paul does not shy away from the "despotic" sides of God (Rom. 1:18, 9:14-29 etc.). As God's chief servant and end-time messenger, Paul knew he was bringing both salvation and death (2 Cor. 2:14-17). But not only God's mighty warrior, he was also a prisoner of war (Phil. 1:9), publicly condemned to death in his service (1 Cor. 4:8-9). All the spectrum is used, from God's vice-roy to his most humiliated chattel. In Romans 6, the slave imagery is used to describe 
the addressees' transition from obedient slaves of sin to "slaves of righteousness" (v. 18), indeed "of God" (v. 22). The Christians are free, but should all the more so be "obedient" to God (v. 17). They are now under the "law" of Christ (Gal. 6:2; cf. 1 Cor. 9:21), of the Spirit (Rom. $8: 2$ ), or of faith (Rom. 3:27). At the same time, paradoxically, the ideal of freedom is Paul's central theological motto.

Clearly, then, some vital aspects of the patriarchal master/slave relation, both as metaphorical appropriation and as its sharp reversal, are included in Paul's religious and social ethos. There are also some indications that Paul was metaphorizing on patron/client relations, with Paul acting as a mediator ("broker") between patron (God) and client

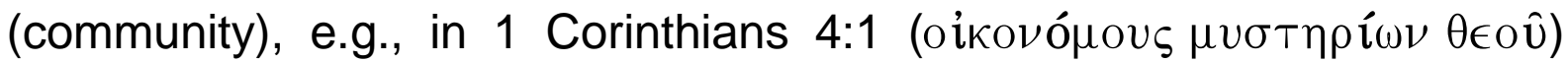

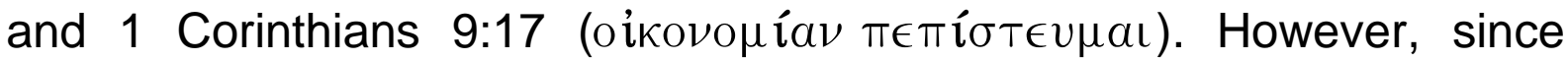
these allusions are usually mixed with other, more pregnant metaphors, Stephan J. Joubert's (1995:216) interpretation of Paul as "broker for the heavenly patrons" seems unduly etic. More appropriate is Joubert's description that Paul in his relation to the (Corinthian) community took the role of a paterfamilias. This image is not quite explicit in Paul, either, even though the metaphor of father appears in practically all Pauline letters. Since family, as noted before, is where patriarchal household structures and bonds of mutual love and care conjoin, this metaphorical field is crucial when we try to understand how the two categories of power are tangled in Paul.

One thing especially is characteristic for Paul's "fatherly" role: it is extremely passionate and intimate, to the extent that it embraces birthing and parenting. These functions are frequently evoked when the readers are exhorted to imitate Paul. Through the gospel, Paul "gave birth" $(\varepsilon \gamma \varepsilon \dot{\varepsilon} \nu \eta \sigma \alpha)$ to the Corinthians (1 Cor. 4:15), so that they are to imitate him. In their early days, when they had been "babes in Christ", he had taught them accordingly: "I fed you with milk, not solid food" (1 Cor. 3:1-

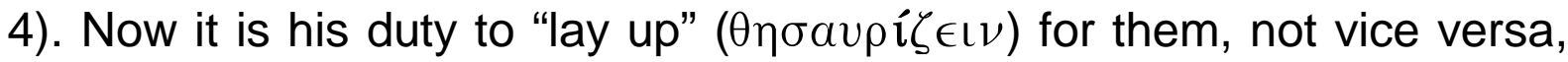
because they are his own children (2 Cor. 12:14) - a reason for his refusal to take money from the community. In Galathians 4:19, Paul describes his feelings like a desperate parent: "My little children, with whom I am again in travail until Christ be formed in you!" Among the Thessalonians, Paul was gentle and soft (lit. "babe"!) towards his new converts, "like a nurse suckling her children" (1 Thess. 2:7). The subsequent (partly repetitive and more formal) section 1 Thessalonians 2:912 then reasons that Paul's "holy, righteous and blameless" behaviour should inspire the community to lead a decent life, in the way Paul himself had exhorted each member of the community "like a farther (deals with) his children". Having left the community so soon, Paul felt 
bereavement like a parent who lost a child ( $\dot{\alpha} \pi \circ \rho \phi a \nu \iota \sigma \theta \varepsilon \dot{\varepsilon} \nu \tau \epsilon$, v. 17). The parenthood imagery is also employed when the growth and maturing of the believers are depicted (Williams, 1999:56-63).

Looking behind the metaphors, we see that Paul is evoking an informal authority. It is often though not necessarily gentle and soft, but it is always unquestionable and lifelong, as fatherhood is. In Weberian terms, it is charismatic authority, perhaps routinized as Bengt Holmberg (1980: 137-160) suggests. It combines "power over" and "power with" in an even more intricate way as does the householder-father's joined economic-legal and emotional-personal authority.

According to Joubert, Paul's intimate parental image in 1-2 Corinthians is but a mask for his patriarchal superiority. The seemingly humble roles he took as ambassador (2 Cor. 5:20), servant (1 Cor. 4:1) and builder (1 Cor. 1:11), and the egalitarian images of the addressees as brothers and partners (2 Cor. 8:23), all "masked a relationship other than the one they implied" (Joubert 1995:217). This interpretation is partial, and it is probably contrafactual that the Corinthians "were socially inferior to (Paul), because he had the authority to command their obedience" (Joubert 1995:217) - socially some members of the community must have been above him, and his ability to command was based on charismatic authority, which was precisely as binding as the Corinthians consented. Moreover, this functional etic interpretation is not likely to correspond with Paul's own experience, because he had probably internalised his parental role. Yet, Joubert's final conclusion (1995:222) seems justified: "Although Paul oscillated between hierarchical and intimate aspects of his patriarchal role ... he still, at all times, claimed the superordinate position for himself."

Comparable conclusions are reached by some recent feminist rhetorical analysts. Cynthia Briggs Kittredge, in her important study Community and authority: The rhetoric of obedience in the Pauline tradition (1998) has explored the Pauline language of obedience socio-rhetorically. Her main focus is on Philippians and Ephesians. Sandra Hack Polaski's Paul and the discourse of power (1999) analyses the letter to Philemon from a postmodern viewpoint, using a Foucaultian genealogical approach. She observes how Paul rejects the possibility to "command" and adopts a language of mutuality, skilfully restricting Philemon's options by threatening him with the loss of friendship.

Paul's power claims emerge in the various ways in which he moves beyond this language of mutuality, manipulating distance and identity in such a way that to be 'with' Paul, that is, on Paul's side, is to seek 
to be 'with' Paul in physical presence and in unity of vision (Polaski, 1999:60).

Turning to Galatians, Polaski finds a similar persuasive strategy at work. Though church structures today are more explicit and institutionalised, the author (in her "Afterword") finds a similar power play going on in her own community.

How, then, do we best understand historically this extremely subtle Pauline combination of power relations? Concentrating on the two fronts of interpretation sketched in the introductory part of this article, we may contrast Theissen's "moderate" interpretation with Horsley's "radical" stance. For Horsley, the hierarchic power structures and the stress on mutual care and "brotherly" love converge in the image of a "political" Paul. His is a counter-imperial and apocalyptic Paul who is busy forming a new alternative society of equals in the spirit of the baptismal formula of Galatians 3:28. For all the differences his Paul shows in comparison with Theissen's portrayal of the apostle, in both cases the image of a community builder is vital. For Horsley, this allows a continuity from Jesus to Paul in terms of a counter-cultural movement, while for Theissen the gap between the itinerant charismatics of the Palestinian Jesus movement and Paul's urban mission is more constitutive.

The strongly personal traits in Paul's authority claim make one wonder, however, if the historical Paul really was an ingenious community organiser. Those with great vision and charismatic vigour are not always the most cunning organisers. Charismatic leaders who tie their followers to themselves and are jealous for competitors, do not necessarily build up a well-structured community. Holmberg's (1980:112) general impression is that in Paul's letters the local offices were rather unimportant. Holmberg observes that they are seldom mentioned, and there are a number of functions they could be expected to have performed but seem not be doing: they do not represent the church to outside authorities, they are not responsible for any central church fund, they are not in charge of church discipline, nor do they act as arbitrators between Christian brothers. When serious conflicts arise Paul does not ask the local leaders to settle them. "We are only seeing the beginning of what was later to mature into a fully-developed office structure" (Holmberg, 1980:113).

Part of the explanation for the invisibility of "office holders" might be that Paul did not recognise them as such. For instance, eminent householders could obviously represent the community to civil authorities and assist in many ways, but they do not seem to be officially authorised or appointed by Paul. Much of the development may have taken place 
without Paul's interference - as long as his authority was not questioned. It is striking how much of Paul's practical advice in 1-2 Corinthians deals with community gatherings instead of community organisation. 1 Corinthians 12, which seemingly argues for an advanced church structure with a variety of tasks, in fact only gives an ideal picture of a community meeting, as becomes clear in chapter 14. But behind the stress laid on the importance of each member with his or her special gift, there is none the less hierarchy of values and tasks: "And God has appointed in the church first apostles, second prophets, third teachers, then workers of miracles ..., speakers in various kinds of tongues" (v. 28). If 1 Corinthians 12:27-31 comes from Paul, then his answer to the question, "Are all apostles?" was a definite no: in his communities there was only one apostle. 1 Corinthians 13 then praises the gift of love in such a way that it in effect becomes a praise for the apostle's self-giving love for the community (cf. how vv. 1-3 reverse the order of 12:28: speaking in tongues, prophesying and performing miracles, sacrificing one's life for others' sake), and eventually pictures the apostle as the paradigmatic "I" for all believers (vv. 11-12).

To be sure, Theissen does admit that there is continuity between the Palestinian Jesus movement and Paul's mission. Besides making the obvious point that Paul, too, was an itinerant charismatic, Theissen has paid attention to one particular ideological factor that helped to preserve the radical ethos in a church that was adopting a more moderate ethic. This factor he identifies as the mythical shaping of the Christ event in the form of a reversal of power relations. In this mythical reversal, Theissen notes, Christ himself becomes the primal model of a renunciation of power and possessions. He is the power of God which revealed itself in the cross as weakness: (2 Cor. 8:9). Myth and ethic form a unity, Theissen contends. "Through myth a radical ethic is preserved which can continue to have an effect long after the ethic which is in fact practised has already become much more 'moderate'” (Theissen, 1999:98-99).

Myth and ethic also form a unity in ethos, inasmuch ethos, as we defined it, includes abstract ideal elements - values and hopes - that motivate or legitimate a person's or a group's practices and habits. The early Christian ethos that most resonates with the myth of reversal is that which receives its social dynamism from self-stigmatization, which I would define as the voluntary acceptance and symbolic reversal of a denigratory identity trait attributed to one by outsiders: the shameful description suggested by the opponents or "the world" is accepted by the identity bearer but turned into an honour. Theissen has paid close attention to this socio-psychological phenomenon, which he finds both in the early Jesus movement and in Paul. In a useful Heidelberg dissertation, his student Helmut Mödritzer (1994) elaborates further on the relationship 
between self-stigmatization and charismatic authority, and draws a trajectory from John the Baptist and Jesus to Paul and on to Ignatius of Antioch, the martyr bishop who advanced episcopal authority.

Here is a promising path of inquiry that may shed light on the religious and social dynamics we see in Paul. However, we must be careful not to turn the social psychological phenomena of stigmatization and selfstigmatization into the theological language of a theologia crucis, where the power aspects are overlooked. We should also notice the peculiarity of the combination we see in Paul of humbleness and pride, of parental self-sacrifice and authority claim. Only Paul dared to say: "Henceforth let no man trouble me; for I bear on my body the marks (or wounds, $\sigma \tau i \gamma \mu \alpha \tau a)$ of Jesus" (Gal. 6:17). This subtle rhetoric of power where obedience is expected to grow out of gratitude has its strengths and weaknesses. While admiring it we should be aware of its ambiguity and potentially dangerous effects. One arbitrary effect was the elevated portrait of Paul, initiated by the apostle himself and carried further by the deutero-Pauline letters, probably beginning with Colossians 1:24: "Now I rejoice in my sufferings for your sake, and in my flesh I complete what is lacking in Christ's afflictions for the sake of his body, that is, the church." A more serious effect, I surmise, was that the Pauline combination of self-sacrifice and obedience became an institutionalised power structure, in practice often with the latter aspect being dominant. Perhaps church history could have taken another turn, if Paul's whole combination of stigmatized and disciplined bodiliness, where the sublimation of thisworldly goods was regulated in a more Stoic way, had prevailed. (The three aspects of early Christian bodiliness are briefly sketched in Syreeni, 1998:210-215.) But that would be an imaginary ideal story. I will now discuss some possible stories that interpret what really happened.

\section{From Paul to the love patriarchalism of the household codes: Some possible stories}

I hope to have shown, even if in a very fragmentary way, some hermeneutical problems in assessing Paul's relation to the post-Pauline ethos of love patriarchalism. My positive conclusions are scanty but may allow some further suggestions for the next step, which is constructing historical "routes" from Paul to deutero-Paulines. In addition to the "radical" myth of the Fall of Man and the "moderate" story of the Great Success, several other plots might be designed, some more plausible than others, but no one story is the whole truth. One possible story, suggested by Peter Lampe and Ulrich Luz, might be labelled, When the end-expectation fades: 
Prophecy, the charismatic-ecstatic expressions of faith, an eschatology geared at a near expectation of the end time - these legacies inherited from the first Christian generation were put aside as remnants to be cared for by special groups. Interestingly enough, however, these very legacies were connected with an advanced emancipation of women. What, however, happens when the expectation fades, as happened in post-Pauline Christianity? Then new, socially integrating concepts have to be introduced. One of these, in our view, was the concept of a patriarchalism of love, which favored a more fixed, hierarchical ordering yet did not allow it to become completely overbearing, because it appealed to those involved, especially those hierarchically superior, to exercise love (Lampe \& Luz, 1993:251).

This is no unlikely scenario in itself, and it aptly records the role of women's emancipation. Its implication, however, is that Paul was not responsible for the development. The concept of love patriarchalism was only introduced after Paul, in a situation where end-expectation had faded and new integrative strategies were needed. Another possible story goes: From the apostle of freedom to the custodians of the trustworthy word (cf. 1 Tim. 3:1 etc.). This would also seem to free Paul from guilt, but we have observed that freedom and obedience go hand in hand in Paul. Moreover, it is interesting that Paul, especially in 1 Corinthians, frequently cites a traditional credal formula to argue for his view (Eriksson, 1998). And if the deutero-Paulines are justified on grounds that they were fighting for the right doctrine, then (apart from what we think of the doctrine) there is the question why women and slaves had to be casualties of this war.

A third story might bear the following title: Paul proclaimed the Gospel of Christ, and the Pauline Church came. This story is as ambivalent as the more famous one about Jesus, the kingdom of God, and the church. One point of disagreement is the definition of the post-Pauline church. Who were the apostle's true heirs? In Theissen's reconstruction, the path is from Paul to the deutero-Pauline letters. Others would find alternative or parallel paths to rescue the historical losers from oblivion: the suppressed or emancipated women, the slaves who remained such or were bought free by community members against the will of their leaders, the apocalyptically minded, the Gnostics. Theissen's trajectory, which is the dominant reconstruction, is not quite compelling but seems plausible enough, whether or not we describe it as a success story. If winners write history, as the deutero-Pauline writers did, it is because they have the power to do it. There were deviant groups, but all the good things were hardly practised in one alternative group. Women's emancipation, for instance, was channelled through various ascetic, apocalyptic and 
Gnostic movements, and to some extent, even through the patriarchal deutero-Pauline communities through patronesses, martyred virgins, influential spouses and understanding mothers.

Paul certainly envisaged a people of God and made it a social reality as much as, and possibly more than Jesus had done. However, if he was a charismatic visionary, rather than an organiser, the social form of the communities was less important to him than was their growth and spiritual wealth. He may have welcomed any church structure as long as it met his ideal description of a spiritual community where believers lived a decent life and gathered in the Lord's name - and as long as his authority passed unquestioned. Since one typical social form in Pauline communities was the congregation of house churches, a strong patriarchal element was there from the start. Paul may have been critical of patronage, but his own authority claim was basically just as patriarchal, though different in nature. He seems to have encouraged the communities' independence from the outside world, which implied interdependence within the communities. That such mutuality de facto often involved a patron's power over his or her dependants need not have worried Paul as far as it had the appearance of "hospitality" and "brotherly" love. Paul's cautious strategy obviously served a socially integrative function. Whether it is love patriarchalism in the same sense as in the household codes remains an open issue. Obedience was one of the cornerstones of Paul's religio-social ethos, but it meant first and foremost loyalty to his authority as the proclaimer of the crucified and risen Lord.

Finally, let us consider the plot development of the story: From Paul the celibate to bishops of one woman. Among the most stunning developments from Paul to the Pastoral Letters is how Paul the celibate became the father of his "beloved child" Timothy (2 Tim. 1:2; still in 1 Tim. 1:2 "my true child in faith") and the advocate for an episcopate of married men. As Dale Martin (1995:209) remarks, "nowhere in Paul's genuine letters does he unreservedly endorse marriage or family". It is quite another Paul who in the First Letter to Timothy summons:

Now a bishop must be above reproach, the husband of one wife ... He must manage his own household well, keeping his children submissive and respectful in every way; for if a man does not know how to manage his own household, how can he care for God's church? (1 Tim. 3:4-5).

To understand this change we need to assume that household became the dominant community structure in post-Pauline churches. Those who would best qualify for the bishop's "noble task" were thus the most 
prominent heads of Christian households. A householder had to be married and with children, so Paul's ascetic ideal had to be modified. We saw previously that Paul in a way initiated this change by considering his celibacy a special gift. As a sign of devotion to the office, and to show an appropriate measure of asceticism (though more lenient than Paul's measure), a widowed househead who was considering candidacy for the bishop's or the deacon's (1 Tim. 3:8-13) office would not remarry. In reality a widowed householder could be a woman, but this possibility is not reckoned with in the Pastoral Letters. Older women only appear as "women" (1 Tim. 3:11), "mothers" (5:2), "real widows" (5:3-6), or something worse. The bishop and the deacons have a substantial economic responsibility, so it is worth stressing that they must not be greedy (3:3.8). On the whole, the patriarchal household order is now evident. However, the reference to "liars" who forbid marriage and advocate stricter asceticism (4:1-5) indicates that not all felt comfortable with this order of things. While it is precarious to extrapolate a particular "women's church" from these hints, it is likely that there were many virgins and widows among the dissatisfied.

With Colossians and Ephesians we are historically closer to Paul, but the Haustafeln in these writings already pave the way to the Pastoral Letters. Thus one (covert) function of the household codes in general seems to have been to establish the episcopal order. Both Colossians and Ephesians develop Paul's oikovouía metaphor (1 Cor. 4:1-3 and 1 Cor. $9: 17)$, focusing on the theological aspects of the economy of God, but their interest in this imagery may indicate that the proper management of the community's money (common fund, wages) was already becoming an issue. Consonant with the economic view of the church is the household image of the Christian family, where the patriarchal hierarchy is stressed. Ephesians 5:23-24 extends the Pauline (?) $\kappa \epsilon \phi a \lambda \eta$ structure of 1 Corinthians 11:3 beyond the worship context to regulate relations within the household. At the same time, the hierarchy is applied ecclesiologically. Christ is not simply "head" of the man, but of the church (Eph. 4:15-16; already Col. 1:18). Thus an analogy exists between Christ and the church on the one hand and husband and wife on the other. Both relations are hierarchic, yet intimate and mutual. Husbands should love their wives (Col. 3:19) as Christ did the church and gave himself up for her (Eph. 5:25). Here the arbitrary effects of Paul's ethos of selfsacrifice and obedience become visible. The household rules of Colossians and Ephesians can naturally be interpreted "positively" (i.e., apologetically) by stressing the reciprocality of the relations. The subordination required (!) is voluntary and ameliorated by the demands placed upon those in authority: they must be loving husbands, caring and non-provocative fathers, and just and fair masters. This is indeed love 
patriarchalism, notes David G. Horrell (1995:232). But, he continues, the appeal for voluntary subordination has an ideological bias as it serves the interests of the superior part; the domestic codes of Colossians and Ephesians provide an ideology for the household (Horrell, 1995:233). Margaret Y. MacDonald (1988:121-122) is justified to conclude: "The Colossian and Ephesian Haustafeln represent a placing of power more firmly in the hands of the rulers of the households (husbands, fathers, masters), ensuring that leadership positions fall to members of this group."

Paul hardly foresaw all this development. The hierarchic and reciprocal structure of the household rules is congenial but not identical with his teaching. He might have objected to many developments that took place, including the marital ideology, but would he have shown more appreciation for rebel virgins than did his later apocryphal counterpart in The Acts of Paul and Thecla? We simply cannot tell.

There are certainly many other stories that might be considered and found both illuminating and problematic. But while Paul can hardly be blamed for all the unhappy development in the churches that cherished his legacy, I do not think he is totally blameless. And in the primary hermeneutical sense, his guilt or innocence does not necessarily matter, because the Pauline heritage, through the deutero-Pauline letters and the subsequent church history, is ours - at our will. It includes much that we find valuable, as well as things we need to reconsider and then change, as generations before us have done. I enclose the wise words of Antoinette Clark Wire (1998:291), after reading her forefather's last will from 1754, where among other things he gives his loving son "ten young negros" together with "my great Bible and all my law books". This is her reaction, and as I believe, the best response to the ambiguous Pauline and deutero-Pauline heritage of love patriarchalism:

What do I do with such a heritage? Change my name? Hide this page and read the rest to my grandson? But what is shameful should be heard. This is family history, mine and that of others descended from those who were enslaved, and I must go through it rather than around it. Likewise Paul and the enslaved people whose lives shaped his writings are our collective family history. The shame and glory are tangled, and this 'mess of pottage' is our precious heritage.

\section{Bibliography}

AEJMELAEUS, Lars. 2002. The question of salary in the conflict between Paul and the 'Super Apostles' in Corinth. (In Dunderberg, Ismo; Tuckett, Christopher \& Syreeni, Kari, eds. Fair play: Diversity and conflicts in early Christianity. FS Heikki Räisänen. Leiden/Boston/Köln : Brill. p. 343-376.) 
BROWN, Peter. 1988. The body and society: Men, women, and sexual renunciation in early Christianity. New York : Columbia University Press.

CHOW, John K. 1992. Patronage and power: A study of social networks in Corinth. JSNTS, 75. Sheffield : Sheffield Academic Press.

ELLIOTT, Neil. 1994. The justice of God and the politics of the apostle. Maryknoll : Orbis Books.

ENGBERG-PEDERSEN, Troels. 2000. Paul and the Stoics. Louisville : Westminster John Knox Press.

ERIKSSON, Anders. 1998. Traditions as rhetorical proof: Pauline argumentation in 1 Corinthians. CBNTS 29. Stockholm : Almqvist \& Wiksell International.

HOLMBERG, Bengt. 1980. Paul and power: The structure of authority in primitive church as reflected in the Pauline Epistles. Philadelphia : Fortress.

HORRELL, David G. 1995. The development of theological ideology in Pauline Christianity: A structuration theory perspective. (In Esler, Philip F., ed. Modelling early Christianity: Social-scientific studies of the New Testament and its context. New York/London : Routledge. p. 224-236.)

HORSLEY, Richard A. 1998a. Paul and slavery: A critical alternative to recent readings. Semeia, 83/84:53-200.

HORSLEY, Richard A. 1998b. 1 Corinthians. Abingdon New Testament Commentaries. Nashville : Abingdon.

JOUBERT, Stephan J. 1995. Managing the household: Paul as paterfamilias of the Christian household group in Corinth. (In Esler, Philip F., ed. Modelling early Christianity: Social-scientific studies of the New Testament and its context. New York/London : Routledge. p. 213-223.)

JUDGE, E.A. 1960. The social pattern of the Christian groups in the first century: Some prolegomena to the study of New Testament ideas of social obligation. London : Tyndale.

KECK, Leander E. 1974. On the ethos of early Christians. Journal of the American Academy of Religion, 42:435-452.

KITTREDGE, Cynthia Briggs. 1998. Community and authority: The rhetoric of obedience in the Pauline tradition. Harvard Theological Studies 45. Harrisburg : Trinity Press International.

KLOPPENBORG, John S. 1998. Status und Wohltätigkeit bei Paulus und Jakobus. (In Hoppe, Rudolf \& Busse, Ulrich, eds. Von Jesus zum Christus: christologische Studien. FS Paul Hoffmann. BZNW 93. Berlin/New York : De Gruyter. p. 127-154.)

LAMPE, Peter, \& LUZ, Ulrich. 1993. Post-Pauline Christianity and pagan society. (In Becker, Jürgen, ed. Christian beginnings: Word and community from Jesus to Post-Apostolic Times. Louisville : Westminster John Knox Press. p. 242-280.)

LASSEN, Eva Maria Lassen. 1997. The Roman family: Ideal and metaphor. (In Moxnes, Halvor, ed. Constructing early Christian families. Peabody : Hendrickson. p. 103-120.)

MACDONALD, Margaret Y. 1988. The Pauline churches: A socio-historical study of institutionalization in the Pauline and Deutero-Pauline writings. SNTSMS 60. Cambridge : Cambridge University Press.

MARTIN, Dale B. 1995. The Corinthian body. New Haven/London : Yale University Press.

MARTIN, Dale B. 1997. Paul without passion: On Paul's rejection of desire in sex and marriage. (In Moxnes, Halvor, ed. Constructing early Christian families. Peabody : Hendrickson. p. 201-215.) 
MEGGITT, Justin J. 1998. Paul, poverty and survival. Studies of the New Testament and its world. Edinburgh : Clark.

MÖDRITZER, Helmut. 1994. Stigma und Charisma im Neuen Testament und seiner Umwelt: Zur Soziologie des Urchristentums. Novum Testamentum et Orbis Antiquus 28. Göttingen : Vandenhoeck \& Ruprecht.

MOXNES, Halvor. 1995. Patron-client relations and the new community in Luke-Acts. (In Neyrey, Jerome H., ed. The social world of Luke-Acts: Models for interpretation. Peabody : Hendrickson. p. 241-268.)

MOXNES, Halvor, ed. 1997. Constructing early Christian families: Family as social reality and metaphor. New York/London : Routledge.

MOXNES, Halvor. 1997. What is family? Problems in constructing early Christian families. (In Moxnes, Halvor, ed. Constructing early Christian families: Family as social reality and metaphor. New York/London : Routledge. p. 13-41.)

MURPHY-O'CONNOR, Jerome. 1997. Paul: A critical life. Oxford : Oxford University Press.

O'BRIEN, Peter T. 1982. Colossians, Philemon. Word Biblical Commentary. Waxo : Word.

PATTERSON, Orlando. 1998. Paul, slavery and freedom: Personal and sociohistorical reflections. Semeia, 83/84:263-293.

POLASKI, Sandra Hack. 1999. Paul and the discourse of power. Gender, culture, theory 8/The Biblical Seminar 62. Sheffield : Sheffield Academic Press.

ROBINSON, James M. \& KOESTER, Helmut. 1971. Trajectories through early Christianity. Philadelphia : Fortress.

SCHÜSSLER FIORENZA, Elisabeth. 1983. In memory of her: A feminist theological reconstruction of Christian origins. New York : Crossroads.

SCHÜTZ, John H. Schütz. 1982. Introduction. (In Theissen, Gerd. The social setting of Pauline Christianity: Essays on Corinth. Philadelphia : Fortress. p. 1-23.)

SCHÄFER, Klaus. 1989. Gemeinde als Bruderschaft. Bern : Peter Lang.

SYREENI, Kari. 1998. Den sublimerade kroppen: Jesu kroppslighet som symbol i Johannesevangeliet. Svensk Exegetisk Årkrift, 63:201-215.

THEISSEN, Gerd. 1976. Itinerant radicalism: The tradition of Jesus sayings from the perspective of the sociology of literature. (In Gottwald, N.K. \& Wire, A.C., eds. The Bible and liberation: Political and social hermeneutics, Berkeley : Radical Religion Reader. p. 84-93.)

THEISSEN, Gerd. 1982. The social setting of Pauline Christianity: Essays on Corinth. Ed. and trans. with an introduction by John H. Schütz. Philadelphia : Fortress.

THEISSEN, Gerd. 1999. A theory of primitive Christian religion. London : SCM.

TROELTSCH, Ernst. 1912. Die Soziallehren der christlichen Kirchen und Gruppen. Gesammelte Schriften. Vol. I. Tübingen : Mohr.

WANSINK, Craig S. 1996. Chained in Christ: The experience and rhetoric of Paul's imprisonments. JSNTS, 130. Sheffield : Sheffield Academic Press.

WINTER, Bruce W. 2001. After Paul left Corinth: The influence of secular ethics and social change. Grand Rapids/Cambridge : Eerdmans.

WILLIAMS, David J. 1999. Paul's metaphors: Their content and character. Peabody : Hendrickson.

WIRE, Antoinette Clark. 1998. Reading our heritage: A response. Semeia, 83/84:283-293. 


\section{Key concepts:}

love patriarchalism

Pauline community structures

Theissen, Gerd: sociological studies on Paul

Troeltsch: hierarchic church structure; family relations

\section{Kernbegrippe:}

patriargalisme van liefde

Pauliniese samelewingstrukture

Theissen, Gerd: sosiologiese ondersoek van Paulus

Troeltsch: hiërargiese kerkstrukture; gesinsverhoudings 